\title{
Current Account Deficit and Automotive Sector Nexus in Turkey: An Input-Output Analysis
}

Banu ERKÖK (https://orcid.org/0000-0002-3410-9210), Finance \& Insurance Operations Department, Turk Eximbank, Turkey; e-mail: berkok@eximbank.gov.tr, berkok@gmail.com

\section{Türkiye'de Otomotiv Sektörü ve Cari İşlemler Açı̆̆ı İlişsisi: Bir Girdi Çıktı Analizi}

\begin{abstract}
The automotive sector plays a significant role in the Turkish economy in creating relatively high added value and employment and accelerating the country's global trade share. The sector is so substantial that it has become the leader in Turkish exports in the last decade. There are plenty of papers in the literature regarding the automotive sector and economic growth nexus and implementing various methods. Still, hardly any studies focus merely on the current account deficits the sector generates, incorporating an input-output analysis. This paper examines the automotive sector and current account deficit nexus through input-output analysis. The results highlight that the automotive sector is highly dependent on imports.
\end{abstract}

Keywords

The Automotive Sector, Current Account Deficit, Input-Output Analysis, Import Dependency, Leakage Coefficients.

JEL Classification Codes : C67, D57, L62.

$\ddot{\mathbf{O} z}$

Otomotiv sektörü görece yüksek katma değer ve küresel ticaretten aldığı pay ile Türkiye ihracatı açısından büyük önem taşımaktadır. Öyle ki son yıllarda Türkiye ihracatının (\%17-18) lokomotifi konumuna ulaşmıştır. Literatürde sektörünün ekonomiye katkısını regresyon ve benzeri analizlerle ortaya koymayı amaçlayan birçok çalışma bulunmaktadır. Ancak sektör üretiminin cari işlemler açığına etkisini girdi çıktı analizi kapsamında değerlendiren az sayıda çalışma bulunduğu gözlemlenmiştir. Bu bağlamda bu çalışmada girdi çıktı analizi kapsamında, sektör üretiminin cari işlemler hesabına etkisinin ortaya konulması amaçlanmıştır. TÜİK tarafından yayınlanan 2012 yılına ait girdi-çıktı tablolarından sektöre yönelik sızıntı ve bağlantı katsayıları hesaplanmış; sektörün üretim aşamasında ithalata bağımlı olduğu tespit edilmiştir.

Anahtar Sözcükler $\quad$ : Otomotiv Sektörü, Cari İşlemler Açığı, Girdi Çıktı Analizi, İthalat Bağımlılığı, Sızıntı Katsayıları. 
Erkök, B. (2021), "Current Account Deficit and Automotive Sector Nexus in Turkey: An Input-Output Analysis", Sosyoekonomi, 29(49), 113-129.

\section{Introduction}

Developing countries, including Turkey, have commenced adopting the export-led growth model for development and sustainable economic growth mainly since 1980. In this respect, production - particularly in sectors that have relatively high comparative advantageis fostered via various government incentives, mainly for the export drive. The automotive sector (AS hereafter) is one of the sectors under consideration. AS, primarily comprised of multinationals, has an essential place in government budgets with its relatively high valueadded structure, contribution to employment and the balance of payments and tax revenue from the sale of products in the sector. Besides, the AS contributes significantly to the countries' economic growth with its relatively high potential that meets the demands of tourism, defence, construction, agriculture, transport, and infrastructure sectors. Moreover, the AS contributes to the economic growth via the huge volume of business it generates in the finance and insurance sectors. The AS is a moderately labour-intensive sector, and relatively low labour costs attract the multinationals ${ }^{1}$ to invest in Turkey. What's more, Turkey's integration to Customs Union of the European Union and its strategic position to reach the domestic markets of the European community are the other motivations for the global companies to operate in Turkey. In this regard, these multinationals hold a crucial place for the development of the Turkish economy. Furthermore, the AS has become the leader sector in Turkish exports for more than fifteen years thanks to these multinationals. According to the "Turkey's Top Ten Industrial Enterprises / 2019" report, issued by Istanbul Chamber of Industry, five global companies operating in the AS are located among Turkey's top ten exporter companies.

On the other hand, as stated by the said report, we can see that total export of the companies is approximately 15,5 billion and 15 billion dollars in 2018 and 2019, respectively. Nevertheless, the total import of the companies is almost 11 billion and 10 billion dollars, respectively in the given years. In other words, we can say that these global companies cause 4,5 billion and 5 billion dollars of current account deficit for Turkey.

As well as the AS, production in the manufacturing industry in Turkey has become more dependent on imported intermediate goods to such an extent that the imported intermediate goods constitute approximately 75 percent of Turkey's total imports. Lack of innovation, technology, and capital accumulation are the main reasons for accelerating the volume of imported inputs. Besides, price and quality advantages are the other factors that lead the manufacturing industry to utilizing imported inputs. Consequently, imported inputs dependency has become a structural characteristic of the Turkish economy (Erduman et al., 2019).

High import dependency in production triggers high current account deficits, exposing the economy to fluctuations in exchange rates. High import requirement is among

1 The list of multinationals operating in AS can be seen: Home Page - ISO $500 \mid$ Türkiye'nin 500 Büyük Sanayi Kuruluşu, <iso500.org.tr >, 16.04.2021. 
the structural factors that bring about current account deficit during high growth periods and decrease the foreign trade incomes (Erduman et al., 2019).

Moreover, high import dependency, by means of increasing the need for foreign financing, puts pressure on the Turkish economy's fragile structure. Subsequently, Turkey's relatively permanent nature of the economic crises has its roots in the production structure of the Turkish economy (Senesen \& Senesen, 2003), which is highly dependent on imported inputs. Essentially, high import dependency is not considered a critical phenomenon for a developed economy with a competitive advantage in the global markets. In those developed economies, huge incomes generated from exports can finance the imports. However, as a developing economy, this high dependency on imported intermediate goods induces a less stable pattern for the growth of the economy in the case of Turkey.

In this context, through input-output (I-O hereafter) analysis, this paper sets out to highlight the dependence on imports of the Turkish AS and its interaction with other sectors that provide input. With I-O analysis, linkages between sectors and changes in the economy can be calculated. The I-O analysis began with Leontief (1936), who used Tableau Economique first by Quesnay (1894). Leontief created an analytical model that can be applied to any economic system. In addition to Leontief, Rasmussen (1956) and Hirschman (1958) developed the concept of the "key sector" making a significant contribution to I-O analysis. However, examining the literature, we can see that less attention has been paid to the distinction between imported and domestically produced inputs, especially on AS via I$\mathrm{O}$ analysis. In particular, investigating the impact of international trade on the linkages and finding out how it influences an economy's overall interdependence plays an essential role in finding out if higher import dependence may result in lower linkages among domestic production. Smith and Sarabi (2020) provided an analysis of the UK's role in the automotive sector, focusing on the UK's trading relationship within and between regions, in which they found out a high level of integration with Europe and Central Asia. They have also revealed that outside the region, there appears to be a trend towards sourcing inputs from East Asia and Pacific and the Middle East and North Africa acting as an export destination. In their paper investigating the Portuguese sectoral interdependence, Reis and Rua (2009) found out that an increase in the coefficient of interdependence seems to be associated with a decrease of the coefficient of leakage and vice versa. Moreover, they underlined that a sector's multiplier effect is higher when the linkages are more spread out over the economy. Timmer et al., (2015) evaluated the geographical and factorial distribution of value-added in global automotive production and revealed increasing fragmentation, both within and across regions. They also calculated the global value chain income in AS, where they found that Turkey's share is less than 1 percent $^{2}$ of the world. The paper also calculated the regional value-added distribution of the final output of automotive by country of completion. Besides, they also found out that Turkey has a final output of 12,371 million US dollars in 2008 where value-added shares in 2008 are (i) domestic (ii) regional (iii) global are as follows $0,64,0,20$

$20,64,0,40,0,70$ and 0,66 in 1995, 2002, 2008 and 2011 respectively. 
and 0,16 and change in shares (2008 minus 1995) are as follows $-0.17,0.07$ and 0.09 respectively. On the other hand, Ünal (2021) highlighted the trade deficits, whereas İnançlı and Konak (2011) emphasized the high import dependency of AS in Turkey. Besides, there are many papers focusing merely on high import dependency in the Turkish economy by IO analysis. Among these, Şenesen and Şenesen (2001) revealed the interconnections between the origins and destinations of intermediate input import dependency induced by final demands within the methodology they proposed. Şenesen and Şenesen (2003) also highlighted the high import dependency in Turkey and mentioned the production structure contributing to the relatively permanent nature of economic crises, exerting pressure on foreign exchange availability. Ersungur and Kizıltan (2007) revealed that the high importdependent structure of the Turkish economy reduces the correlation between the key sectors of the manufacturing sectors rendering the effect of industrialization and production increase inadequate. Analysing the structural changes in exports of an emerging economy, Saygili and Sayg1l (2011) affirmed that structural change in the composition of exports determines the recent changes in parameters of the export equation in Turkey. They also noted that the sectors with high income and imports, but low exchange rate elasticities of exports tended to increase their shares in total Turkish exports.

Within this context, this paper aims to examine the AS and current account deficit nexus through input-output analysis. This paper also seeks to fill the literature gap, primarily focusing on the Turkish AS's imported inputs. For this reason, the linkage coefficients, leakages, power and sensitivity, and key sectors of the Turkish economy from the inputoutput tables of 2012, published by TURKSTAT ${ }^{3}$, are calculated. In the second and third parts of the paper, methodology and results are reported. In the third part of the paper, the findings are discussed.

\section{Methodology}

I-O analysis is a general equilibrium analysis that examines the mutual dependence of the sectors in an economy. For economic planning, the determination of the relation between sectors plays a significant role. In this respect, revealing the relations between the sectors in a specific country's whole economic structure, I-O analysis plays a significant role in economic planning (Küçükkiremitçi, 2013). As an analytical tool, the I-O analysis is utilized by governments when implementing economic policies. The advantage of I-O analysis is that it reveals how changes in the economy affect a specific sector and how changes in one or more sectors affect the entire economy. In this context, it provides the tools to assess structural changes in the economy in terms of linkages between economic sectors. In a free-market economy, the I-O analysis is not concerned with the causes of final demand changes, for these changes are considered "given". Within this framework, since they have been estimated, the I-O analysis will show the activity levels that will have to be met within the endogenous sectors to sustain the final demand level (Miernyk, 2020: 49). While the I-O analysis has been developed within the framework of a market economy, it

Sectors are classified by NACE Rev. 2. 
has been understood that the analysis could be applied to other types of economic systems (Miernyk, 2020: 49). The I-O analysis represents the economy to be studied in terms of aggregated industrial commodity groups or sectors, particularly in assessing how changes in one or more sectors within an economy will affect the entire economy.

The I-O table is a matrix indicating the input requirements of each sector from other sectors to produce one unit of output. The columns consist of (i) each sector's production factors (inputs from other sectors), (ii) the sum of each sector's output, (iii) the total imports (as final good). Namely, the columns indicate the total supply. Moreover, the rows consist of intermediate usage of other sector's output (as input) and the final demand for that sector (including domestic consumption, inventory changes, and exports). In other words, the rows indicate the total utilization.

The I-O table provides a brief and systematic composition of all economic activities within an economy. It reveals the inter-sectoral flows in monetary terms for a particular period where the flows represent intermediate goods /services. The I-O table traces the transactions between the sectors -inter-sectoral flows in a given period in dollar term. The sectors sell goods and services to other sectors and final users or final demand and buy inputs from other sectors and primary sources (Jensen et al., 2017: 18). A hypothetical and muchsimplified transaction table for a 3-sector economy is shown in Table-1. Each row indicates the flows from one sector to other sectors and final demand.

Table: 1

\section{Hypothetical Transaction Table (dollar)}

\begin{tabular}{|c|c|c|c|c|c|}
\hline & Purchasing Sector & & & & \\
\hline \multicolumn{6}{|l|}{ Selling Sectors } \\
\hline & 1 & 2 & 3 & Final Demand & Total Output \\
\hline & Quadrant I & & & Quadrant II & \\
\hline 1 & 25 & 20 & 15 & 40 & 100 \\
\hline 2 & 14 & 6 & 10 & 20 & 50 \\
\hline \multirow[t]{2}{*}{3} & 20 & 12 & 43 & 25 & 100 \\
\hline & Quadrant III & & & Quadrant IV & \\
\hline Primary Inputs & 41 & 12 & 32 & 12 & 97 \\
\hline Total Outlet & 100 & 50 & 100 & 97 & 347 \\
\hline
\end{tabular}

Source: Jensen et al., 2017: 18.

Examining the Table-1, we can see that "sector 1" sells 25 dollars of its output operating in the same sector; 20 dollars in "sector 2"; 15 dollars of its output to "sector 3" and 40 dollars to final users. Examining the Table-1, we can also see that the columns reveal the purchasing pattern of each sector. Thus "sector 3" buys 15 dollars of goods/ services from "sector 1"; 10 dollars from "sector 2"; 43 dollars from "sector 3" and 32 dollars of goods / services in the form of primary inputs. Quadrant I is termed the processing or intermediate quadrant, and it reveals the flows of transactions between the sectors, whereas quadrant II reveals the sales of each sector to final demand -namely consumption, investment, government expenditure, and exports (Jensen et al., 2017: 19). Quadrant III including rows for depreciation, indirect taxes, wages and salaries, gross operating surplus imports, and other value-added items- shows the primary inputs into each sector and mainly 
represents the value-added in production. In contrast, quadrant IV reveals primary inputs which are absorbed by final demand. In general, all endogenous sectors of the economy are included within quadrant I, where the transactions table provides a descriptive snapshot / essential information on particular aspects of a particular economy at a point of time (Jensen et al., 2017: 19). The final demand (minus imports) is considered to indicate GNP on the expenditure side.

The I-O analysis began with Leontief (1936), who used "Tableau Economique" first by Quesnay (1894). Leontief created an analytical model that can be applied to any economic system during the growth period and characterized by two simplifying assumptions: (i) a standard classification is used for goods and production units: the "sector classifies the economy" (ii) although sectors may utilize a variety of goods as inputs, their inputs are not mixed. Each sector is identified with the goods that it produces. By definition, a technical coefficient measures the need for some input per unit of some output (Raa, 2006: 14).

According to the I-O analysis, since one sector uses other sectors' output during production, inter-sector transactions play an essential role in the economy. In other words, the output of a sector is an input of the other sector to produce its output. The primary assumption of the I-O analysis is that each sector has a unique output and homogeneous production function. Another basic assumption of the I-O analysis is that there is a linear correlation between the demand of inputs and outputs.

In addition to Leontief, Hirschman (1958), Rasmussen (1956), Chenery and Watanebe (1958) focused on the linkages between the sectors and developed the I-O analysis, in which Rasmussen (1956) and Hirschman (1958) developed the theory of the "key sector" to make a significant contribution to I-O analysis. The most fundamental challenge of the I-O analysis is calculating the necessary output levels of each sector required to achieve a final output (Hewings, 2020: 7).

The transactions table can be represented by series of equation as follows:

$$
\begin{aligned}
& X 1=X 11+X 12+\ldots \ldots+X 1 n+Y 1 \\
& X 2=X 21+X 22+\ldots \ldots+X 2 n+Y 2 \\
& X n=X n 1+X n 2+\ldots \ldots .+X n m+Y n \\
& \text { where, } \\
& X i=\text { total output of intermediate sector } i \text { (row or column totals) } \\
& X i j=\text { output of sector i purchased by sector } \mathrm{j} \text { (elements of quadrant I) } \\
& Y i=\text { total final demand for the output of sector } \mathrm{i}
\end{aligned}
$$

Dividing the elements of the columns of the transactions table by the respective column totals, we derive coefficients representing plainly the purchasing form of each 
sector. These coefficients are named "direct" or "input- output" coefficients (Lind, 2014). They are notated as aij and represent the direct requirement / inputs from each sector i following an increase in unit output of any sector $\mathrm{j}$ (Lind, 2014).

This can be shown in matrix as follows.

$\mathrm{X}=\mathrm{AX}+\mathrm{Y}$

$\mathrm{nx} 1 \mathrm{nxn} \mathrm{nx} 1 \mathrm{nx} 1$

where $A=[a i j]$, the matrix of input- output coefficients

by transposition we obtain

$\mathrm{X}=(1-\mathrm{A})=\mathrm{Y}$

By solving the above system, we derive the general solution:

$\mathrm{X}=(1-\mathrm{A})-1=\mathrm{Y}$

(1-A) -1 is termed as Leontief inverse matrix.

\section{Linkage Coefficients}

The direct backward linkage coefficient (DBLC) reveals the sum of a sector's intermediate inputs requirement during the production phase. In other words, DBLC indicates the ratio of a sector's input requirement during production. If the production increase in the sector with a high coefficient $(\mathrm{X})$, this increase raises other sectors' production providing inputs $(\mathrm{Y}, \mathrm{Z})^{4}$, and the sectors with high DBLC positively affect the level of production of other sectors. In this context, these sectors can also be defined as locomotive sectors within an economy. The direct forward linkage coefficient (DFLC) is the ratio of the total intermediate sales of one sector to other sectors (total sales of the sector for using other sectors as intermediate goods) to the sector's total production. According to Hirschman (1958: 102), the size of the DFLC informs about the characteristic of each sector. If the DFLC of the sector is relatively high, we can say that the sector's input is utilized as raw material or intermediate goods. If the DFLC of the sector is relatively low, we can consider the related sector as a final goods.

Calculations of DBLC in Equation 1 and DLFC 1 in Equation 2 keep up with Chenery and Watanabe (1958) method as follows:

$$
\begin{aligned}
& D B L C_{i}=\sum_{i=1}^{n} \frac{x_{i j}}{x_{j}}=\sum_{i=1}^{n} a_{i j} \\
& D L F C_{j}=\sum_{j=1}^{n} \frac{x_{i j}}{x_{i}}=\sum_{j=1}^{n} b_{i j}
\end{aligned}
$$

\footnotetext{
4 If $X$ production increases $=>Y, Z$ production also increases, since $X$ uses $Y \& Z$ during production.
} 
The total increase in production in the economy caused by a 1 unit increase in demand in a particular sector is the total backward linkage coefficient (TBLC). The sum of the Leontief inverse matrix columns reveals the TBLC (Miller \& Blair, 2009: 557). On the other hand, TBLC also reveals the production multiplier. In this sense, TBLC refers to the total increase in production in the economy triggered by demand change. The increase in the production of a particular sector by increasing the one-unit increase in all sectors is defined as the total forward linkage coefficient (TFLC). With TFLC, when there is an increase in one-unit demand for all sectors' final products in the economy, the increase in each sector's production is calculated. Rasmussen (1956) adds another methodology to use the column (or row) sums of the Leontief inverse (L), which can be calculated with $L=(I-A)-1$ in where $\mathrm{A}$ is I-O table, to calculate inter-sectoral linkages. TBLC in Equation 3 and TLFC 2 in Equation 4 referring to L are calculated as below:

$$
\begin{aligned}
T B L C_{i}^{L} & =\sum_{i=1}^{n} g_{i j} \\
T F L C_{j}^{L} & =\sum_{i=1}^{n} z_{i j}
\end{aligned}
$$

Within an open economy, imported goods are used not only as final goods but also as input. Therefore, increase in production generates an increase in imports, which is called "economic leakage" (Guo \& Planting, 2001). Generally, the I-O table's intermediate transactions are made of the sector's consumption of goods and services regardless of the origin, whether foreign or domestic (Guo and Planting, 2001:8). Within the I-O analysis, the economic leakages are forecasted by separate tables: (i) merely domestic inputs and (ii) merely of imports (Guo \& Planting, 2001: 9).

According to Hirschman, a key sector is the one which has a high forward as well as backward linkage coefficient (Hazari, 1970: 302). On the other hand, key sectors are mainly determined using Rasmussen's power and sensitivity index (Rasmussen, 1957). These are calculated respectively as the average ratio of the sector's DBLC to the average ratio of the DBLC of the economy and the average ratio of the sector's sales to the average economic sales ratio.

Leakage in Equation 8 coefficients that indicate the import dependency of a sector are also calculated below, where Am denotes Import I-O Table, Ad is domestic I-O Table, $\mathrm{Yd}$ is the final demand of certain sector for Turkey:

$$
\begin{aligned}
& X_{i}=\left(I-A_{d}\right)^{-1} Y_{i d} \\
& A_{m} X_{i}=A_{m}\left(I-A_{d}\right)^{-1} Y_{i d} \\
& M_{i}=A_{m}\left(I-A_{d}\right)^{-1} Y_{i d} \\
& L I=A_{m}\left(I-A_{d}\right)^{-1} \\
& \text { Leakage } e_{i}^{L I}=\sum_{i=1}^{n} l_{i j}
\end{aligned}
$$


The interaction of the sectors with other sectors and their dependence on imports was calculated by using I-O tables issued by TURKSTAT 3 for 2012.

To classify a sector by considering its power (P) in Equation 10 and sensitivity (S) in Equation 11 coefficients, followings are calculated:

$$
\begin{gathered}
P_{j}=\frac{\frac{1}{n} g_{i j}}{\frac{1}{n^{2}} \sum_{i=1}^{n} g_{i j}} \\
S_{i}=\frac{\frac{1}{n} Z_{i j}}{\frac{1}{n^{2}} \sum_{j=1}^{n} z_{i j}}
\end{gathered}
$$

Then each sector is classified if it has $P_{j}>1$ and $S_{i}>1$, it is classified as key sector. If it has $P_{j}>1$ and $S_{i}<1$, then is called backward linkage dependent. Alternatively, if it has $P_{j}<1$ and $S_{i}>1$, forward linkage dependent. Lastly, if it satisfies $P_{j}<1$ and $S_{i}<1$, is classified as independent.

\section{Results}

The linkage coefficients, leakages, power and sensitivity, and key sectors of the Turkish economy are calculated from the input-output tables of 2012. The data obtained from TURKSTAT's I-O tables ${ }^{5}$. We can see the (i) original I-O tables, (ii) import I-O tables, and (iii) the domestic import I-O tables, within the tables at basic prices. The tables mainly cover 64 sectors, and each of the I-O Tables assess them together based on these sectors.

DBLC is calculated by the sum of intermediate inputs used from other sectors within the production of AS. The calculations - also shown in Table 7 in appendix- reveal that the DBLC of AS - which has ranked relatively higher ${ }^{6}$ among 64 sectors - is " 0,4962 ". In other words, the AS uses almost 50 units of input from other sectors in its 100-unit production. So, it is appropriate to remark that, due to the relatively high DBLC of AS, a rise in production in AS increases the total production in the economy, respectively. However, it is not correct to state that a sector with a high DBLC affects the production of many sectors. In other words, the critical point to be determined is how many sectors are triggered by an increase in AS production. So, at this point, it is worth determining which sectors' production specifically goes up due to the increase in AS's production. Therefore, the partial DBLCs of AS are calculated. As a result, it has been observed that AS -with the highest coefficient of " 0,1671 "- mostly uses inputs from its own sector during production. Basic metals (with "0.0871") and machinery and equipment (with "0,0350") follow AS, respectively (Table-2). Therefore, we can reveal that the AS does not have a production structure that affects many sectors. During the production of 100 units of output, most inputs used are from its (own) sector (approximately 17 percent). The other sectors are as follows: the basic metals (approximately 9 percent), and machinery and equipment (approximately 4

\footnotetext{
$5<$ <ttp://www.tuik.gov.tr/PreTablo.do?alt_id=1021>.

6 Twenty-first among 64 sectors.
} 
percent), wholesale and retail trade and repair services of motor vehicle (approximately 3 percent) and wholesale trade services, except motor vehicles and motorcycles (approximately 3 percent).

Table: 2

The Partial DBLCs of AS

\begin{tabular}{|l|c|}
\hline Sector & Coefficient \\
\hline Motor vehicles, trailers and semi-trailers (AS) & 0,1671 \\
\hline Basic metals & 0,0871 \\
\hline Machinery and Equipment & 0,0350 \\
\hline Wholesale and retail trade and repair services of motor vehicle & 0,0293 \\
\hline Wholesale trade services, except motor vehicles and motorcycles & 0,0269 \\
\hline
\end{tabular}

Source: Author's own elaboration.

Besides, the $\mathrm{DFLC}^{7}$ of the AS is " 0,2854 ", ranked thirty- second out of 64 sectors (Table 7). In other words, we can reveal that the AS's output is mostly used as a "final good." However, in order to determine the sectors that utilize AS as input, we calculated the partial DFL coefficients of the AS. The results of the calculations reveal that the AS is ranked first with the value of " 0,1671 "; wholesale and retail trade and repair services of motor vehicles and motorcycles is ranked second with the value of " 0,0851 " and machinery and equipment is ranked third out of 64 sectors with the value of " 0,0126 " (Table 3 ). The subsequent sectors are as follows: land transport services, and transport services via pipelines and other transport equipment. Namely, the sectors shown in Table 3 are the ones that primarily use AS as input.

Table: 3

The Partial DFLCs of AS

\begin{tabular}{|l|c|}
\hline Sector & Coefficient \\
\hline Motor vehicles, trailers and semi-trailers (AS) & 0,1671 \\
\hline Wholesale and retail trade and repair services of motor vehicles and motorcycles & 0,0851 \\
\hline Machinery and Equipment & 0,0126 \\
\hline Land transport services and transport services via pipelines & 0,0054 \\
\hline Other transport equipment & 0,0045 \\
\hline
\end{tabular}

Source: Author's own elaboration.

On the other hand, the calculations in Table 7 reveal that the TBLC of AS ranked eighteenth among 64 sectors with a value of "1.9061". In other words, when the final demand for AS increases by 1-unit, total production in the economy increases by approximately 2 units. The relatively high TBLC indicates that AS has a critical position to trigger the economy's production capacity and value chain. Besides, to determine which sectors compose "1.9061" units increase ${ }^{8}$, the partial TBLCs have been calculated. It has been seen that when the final demand for AS increases by 1-unit, total production increase occurs mostly AS's production -with the highest coefficient of " 1.2057 ". Besides basic metals (with "0.1450") and land transport services and transport services via pipelines (with " 0.0484 ") follow AS, respectively (Table 4). Thus, it is understood that after AS the highest production

7 Revealing information about the qualification of the sector's output.

8 Which sectors were mostly affected due to production increase in AS. 
increase occurs in the basic metals and land transport services and transport services via pipelines. The subsequent sectors are as follows: machinery and equipment and wholesale trade services, except of motor vehicles and motorcycles.

Table: 4

The Partial TBLCs of AS

\begin{tabular}{|l|c|}
\hline Sector & Coefficient \\
\hline Motor vehicles, trailers, and semi-trailers (AS) & 1,2057 \\
\hline Basic metals & 0,1450 \\
\hline Land transport services and transport services via pipelines & 0,0484 \\
\hline Machinery and Equipment & 0,0462 \\
\hline Wholesale trade services, except of motor vehicles and motorcycles & 0,0446 \\
\hline
\end{tabular}

Source: Author's own elaboration.

Additionally, the calculations reveal that TFLC ranked thirty-fifth among 64 sectors with a value of "1.4167". Accordingly, when the final demand for whole sectors of the economy increase one unit, AS production will increase by "1.4167" units. This "1.4167" unit increase is composed of increased AS production due to an increase in final demand (in all sectors) and total production increase in the AS to meet demand in other sectors. As a result of the calculation, we see that " 1.2057 " of the " 1.4167 " units, which is the total production increase of the AS, is due to the sector's (own) demand. The distribution of other coefficients making up "1.4167" is as follows: wholesale and retail trade and repair services of motor vehicles and motorcycles $(0,1068)$ and machinery and equipment $(0,0170)$ (Table 5). The subsequent sectors are as follows: land transport services and transport services via pipelines and other transport equipment.

Table: 5

The Partial TFLCs of AS

\begin{tabular}{|l|l|}
\hline Sector & Coefficient \\
\hline Motor vehicles, trailers and semi-trailers (AS) & 1,2057 \\
\hline Wholesale and retail trade and repair services of motor vehicles and motorcycles & 0,1068 \\
\hline Machinery and Equipment & 0,0170 \\
\hline Land transport services and transport services via pipelines & 0,0107 \\
\hline Other transport equipment & 0,0066 \\
\hline
\end{tabular}

Source: Author's own elaboration.

\section{Leakages}

On the other hand, leakage represents the increase in imported inputs due to the increase in production. Examining the leakages, we understood that AS is ranked fifth with the value of $(0,3185)$ among 64 of all Turkish economy sectors. TBLC of AS is "1.9062", the increase in AS production causes an increase in import due to the import dependency of AS. Besides, due to the imported inputs used in production by the sectors providing input to $\mathrm{AS}$, the increase in production of AS causes a " 0,3185 " increase in imported inputs. In other words, when the production for AS increases by "1.9062" due to the increase in final demand and this causes an increase in the import of the intermediate goods and raw materials worth of " 0,3185 ". So, we calculated the coefficients to find out the sectors that make up the import increase of " 0,3185 ", due to the increase in AS's production. As a result, we see that AS 
with the highest coefficient of " 0,2302 " mostly uses imported inputs from its own sector during production. Basic metals (with "0,0304") and rubber and plastic products (with "0,0087") follow AS, respectively. The subsequent sectors are as follows: electricity, gas, steam and air conditioning and machinery and equipment. Therefore, we can conclude that the 1.9062 unit of increase in AS production causes " 0,3185 " leakages (Table 6) which is highly dependent on imported inputs.

Table: 6

\section{Leakage of AS}

\begin{tabular}{|l|c|}
\hline Sector & Coefficient \\
\hline Motor vehicles, trailers and semi-trailers (AS) & 0,2302 \\
\hline Basic metals & 0,0304 \\
\hline Rubber and plastic products & 0,0087 \\
\hline Electricity, gas, steam, and air conditioning & 0,0071 \\
\hline Machinery and equipment & 0,0047 \\
\hline
\end{tabular}

Source: Author's own elaboration.

On the other hand, according to leakage coefficients (Rasmussen categories), it has been understood that $\mathrm{AS}$ is "BL dependent". We also calculated power coefficients to determine the effect of the sectors. According to the power coefficient (normalized total backward linkage) of AS, other sectors will produce approximately 1.1 times higher than their current level if the final demand for it increases. Similarly, given the sensitivity that the economy rises to 1 unit, AS's demand will increase by 0,8 times.

\section{Conclusion}

High import dependency, which increases the need for foreign financing, puts pressure on the Turkish economy's fragile structure. Subsequently, Turkey's relatively permanent structure of the economic crises has its roots in the production framework of the economy, which is highly dependent on intermediate imported goods.

This paper aims to examine the automotive sector and current account deficit nexus through input-output analysis. Evaluating the linkage and leakage, we see that the sector generates leakage and current account deficit, underlining the sector's high import dependency.

The automotive sector plays a significant role in the Turkish economy in creating relatively high added value and employment and accelerating global trade share. The sector has become the leader in Turkish exports in the last decade, thanks to the global companies invested in Turkey. According to the "Turkey's Top Ten Industrial Enterprises / 2019" report, issued by Istanbul Chamber of Industry, five global companies operating in the sector are located among Turkey's top ten exporter companies. Examining the foreign trade figures of these leader exporters, we see that total export of the companies is approximately 15,5 billion dollars, while total import is approximately 11 billion dollars in 2018 . They generated 4,5 billion dollars of foreign trade deficit in 2018. Likewise, 2018, the foreign trade deficit increased to 5 billion dollars, while the total export of companies was approximately 15 
billion dollars and total import is approximately 10 billion dollars in 2019. In other words, they increase not only the export but also the import volume.

The calculations from the input-output tables of 2012 indicate that the automotive sector uses almost 50 units of input from other sectors in its 100-unit production. Due to the relatively high direct backward linkage coefficient, one unit increase in production in the sector increases the total production in the economy. During the production of 100 units of output, most inputs are from its own sector (mainly automobile motors and spare parts, which is approximately 17 percent). The other sectors are as follows:(i) the basic metals (approximately 9 percent), and (ii) machinery and equipment (approximately 4 percent).

Taking the direct forward linkage coefficient into account, we see that the automotive sector's output is a "final good" in the economy. Calculating the sectors that mainly utilize the automotive sector as input are as follows: (i) its own sector, (ii) wholesale and retail trade and repair services of motor vehicles and motorcycles and (iii) machinery and equipment.

Taking the total backward linkage coefficient into account, we see that when the final demand for the automotive sector increases by 1-unit, total production in the economy increases by approximately 2 units. In other words, the automotive sector has a significant potential to trigger the production capacity of economy and value chain. When the final demand for the automotive sector increases by 1-unit, total production increase occurs mainly in its own production sector, where (i) basic metals and (ii) land transport services and transport services via pipelines follow, respectively.

When the final demand for the whole sectors of the economy increase 1 unit, the automotive sector production will increase by approximately 1,5 units, which is mainly due to the sector's (own) demand. The subsequent sectors are as follows: (i) wholesale and retail trade and repair services of motor vehicles and motorcycles and (ii) machinery and equipment.

Examining the leakages, we see that the automotive sector is ranked fifth among all sectors. In other words, the increase in the automotive sector production causes an increase in imports due to the import dependency of the sector. Putting it another way, when the production in the automotive sector increases by approximately 100 units, this increase causes an increase in the import of the intermediate goods and raw materials of 20 units. The sectors that make up the import increase are as follows (i.) its own sector (ii) basic metals, (iii) rubber and plastic products (iv) electricity, gas, steam and air conditioning and (v) machinery and equipment.

Import dependence on production factors creates adverse conditions for economic growth, especially for the developing countries. In this context transforming the automotive sector into a technologically competitive one will support the growth of the economy. The imported inputs (mainly the automobile motors and spare parts) need to be motivated to be produced domestically via different government incentives. In other words, along with the 
Erkök, B. (2021), "Current Account Deficit and Automotive Sector Nexus in Turkey: An Input-Output Analysis”, Sosyoekonomi, 29(49), 113-129.

incentives addressed solely to the automotive sector, deploying the said incentives to the input providers will create a robust automotive sector inducing a stable pattern for the economy's growth. Thus, the added value created will remain in Turkey, supporting the current account deficit, and the targeted production increase will be realized.

\section{References}

Alcantara, V. \& E. Padilla (2003), "Key Sectors in Final Energy Consumption: An Input/Output Application to the Spanish Case", Energy Policy, 31(15), 1673-1678.

Baynes, T. \& M. Lenzen \& J.K. Steinberger \& X. Bai (2011), “Comparison of Household Consumption and Regional Production Approaches to Assess Urban Energy Use and Implications for policy", Energy Policy, 39(11), 7298-7309.

Chen, Z.M. \& G. Chen (2013), "Demand-Driven Energy Requirement of World Economy 2007: A Multi-Region Input-Output Network Simulation”, Communications in Nonlinear Science and Numerical Simulation, 18(7), 1757-1774.

Chenery, H.B. \& T. Watanabe (1958), "International Comparisons of the Structure of Production", Econometrica: Journal of the Econometric Society, 26(4), 487-521.

Chiu, R.H. \& Y.C. Lin (2012), "The Inter-Industrial Linkage of Maritime Sector in Taiwan: An Input-Output Analysis", Applied Economics Letters, 19(4), 337-343.

Driver, C. (1994), "Structural Change in the UK 1974-84: An Input-Output Analysis", Applied Economics, 26(2), 153-158.

Erduman, Y. \& O. Eren \& S. Gül (2019), “The Evolution of Import Content of Production and Exports in Turkey: 2002-2017”, Research and Monetary Policy Department, Central Bank of the Republic of Turkey, Working Paper No: 19/09.

Ersungur, Ş. \& A. Kızıltan (2007), “Türkiye Ekonomisinde İthalata Bağımlılığın Girdi-Çıktı Yöntemiyle Analizi”, Atatürk Üniversitesi Sosyal Bilimler Enstitüsü Dergisi, 9(1), 267 278.

Günlük-Şenesen, G. \& Ü. Şenesen (2001), "Reconsidering Import Dependency In Turkey: The Breakdown of Sectoral Demands with Respect to Suppliers", Economic Systems Research, 13(4), 417-428.

Guo, J. \& M.A. Planting (2001), "Using Input-Output Analysis to Measure U.S. Economic Structural Change Over a 24 Year Period”, Bureau of Economic Analysis Working Paper 2000(01), Washington: US Department of Commerce.

Hazari, B.R. (1970), "Empirical Identification of Key Sectors in the Indian Economy", The Review of Economics and Statistics, 52(3), 301-305.

Hewings, G.J.D. (2020), Regional Input-Output Analysis, West Virginia University, Web Book of Regional Science, <https://researchrepository.wvu.edu/rri-web-book/10>, 10.08.2020.

Hirschman, A.O. (1958), “A Dissenter's Confession: The Strategy of Economic Development", Revisited. in G.M. Meier \& D. Seers (eds.), (1984) Pioneers in Development, Oxford University Press.

İnançlı, S. \& A. Konak (2011), “Türkiye'de İhracatın İthalata Bağımlılığı: Otomotiv Sektörü”, Eskişehir Osmangazi Üniversitesi İktisadi ve İdari Bilimler Dergisi, 6(2), 343-362. 
Istanbul Chamber of Industry “ISO 500” (2020), Turkey's Top 500 Industrial Enterprises 2019 Survey, Home Page - İSO 500 | Türkiye'nin 500 Büyük Sanayi Kuruluşu, <iso500.org.tr>, 16.08.2020.

Jensen, R.C. \& T.D. Mandeville \& N.D. Karunaratne (2017), Regional economic planning: Generation of regional input-output analysis, Google Books.

Korres, G.M. (1996), "Sources of Structural Change: An Input-Output Decomposition Analysis for Greece", Applied Economics Letters, 3(11), 707-710.

Küçükkiremitçi, O. (2013), “Türkiye ve Avrupa Birliği Üyesi Ülkelerin Üretim Yapılarının GirdiÇıktı Analizi ve Benzeşme Testleri Yöntemiyle Karşılaştırılması”, PhD Thesis, Gazi Üniversitesi, Ankara.

Leontief, W.W. (1936), "Quantitative Input and Output Relations in the Economic Systems of the United States", The Review of Economics and Statistics, 18(3), 105-125.

Lind, D. (2014), Value Creation and Structural Change during the Third industrial Revolution. The Swedish Economy from a Vertical Perspective, School of Economics and Management, Department of Economic History, Lund University, Sweden.

Machado, G. \& R. Schaeffer \& E. Worrell (2001), "Energy and Carbon Embodied in the International Trade of Brazil: An Input-Output Approach", Ecological Economics, 39(3), 409-424.

Managi, S. \& D. Karemera (2004), "Input and output biased technological change in US agriculture", Applied Economics Letters, 11(5), 283-286.

Midmore, P. \& M. Munday \& A. Roberts (2006), “Assessing industry linkages using regional inputoutput tables", Regional Studies, 40(3), 329-343.

Miernyk, W.H. (2020), The elements of input-output analysis, Web Book of Regional Science, 6, Regional Research Institute, West Virginia University.

Miller, R.E. \& P.D. Blair (2009), Input-Output Analysis: Foundations And Extensions, Cambridge University Press.

Quesnay, F. (1894), Tableau Economique (First Printed in 1758 and Now Reproduced in Facsimile for the British Economic Association), Macmillan \& Company.

Raa, T.T. (2006), The economics of input-output analysis, Cambridge University Press The Economics of Input-Output Analysis - Thijs ten Raa - Google Kitaplar, 12.04.2020.

Rasmussen, P.N. (1956), Studies in Inter-Sectoral Relations, Holland.

Reis, H. \& A. Rua (2009), “An Input-Output Analysis: Linkages versus Leakages”, International Economic Journal, 23(4), 527-544.

Sayg1l1, H. \& M. Saygilı (2011), "Structural Changes in Exports of an Emerging Economy: Case of Turkey", Structural Change and Economic Dynamics, 22(4), 342-360.

Şenesen, Ü. \& G. Günlük-Şenesen (2003), "Import dependency of production in Turkey: structural change from 1970's to 1990's", Tenth Annual Conference of the Economic Research Forum (ERF), 16-18.

Smith, M. \& Y. Sarabi (2021), "UK Trading Patterns within and Between Regions in the Automotive Sector - A network analysis", The World Economy, 44(2), 510-529.

Sözen, A. \& İ. Alp \& Ü. İskender (2014), “An Evaluation of Turkey’s Energy Dependency”, Economics, Planning and Policy, 9(4), 398-412. 
Sözen, A. (2009), "Future Projection of The Energy Dependency of Turkey Using Artificial Neural Network", Energy Policy, 37(11),4827-4833.

Timmer, M.P. \& E. Dietzenbacher \& B. Los \& R. Stehrer \& G.J. De Vries (2015), “An Illustrated User Guide to the World Input-Output Database: The case of Global Automotive Production", Review of International Economics, 23(3), 575-605.

Toh, M.H. \& S.M. Thangavelu (2013), “An Input-Output Study of the Singapore Information Sector", Economic Systems Research, 25(2), 233-244.

Topcuoğlu, A. \& I.O. Oral (2020), "Importance of Energy for Industries and Role of the Energy Sector in Turkey's Economy”, Dynamics of Energy, Environment and Economy. Lecture Notes in Energy, 77.

Tukker, A. \& E. Dietzenbacher (2013), “Global Multiregional Input-Output Frameworks: An Introduction and Outlook", Economic Systems Research, 25(1),1-19.

Ünal, E. (2021), "Industrial Growth Models by Input-Output Analysis and an Institutional Approach to the Automotive Industry in China and Turkey", Evolutionary and Institutional Economics Review, 18, 175-203.

Watanabe, C. \& M. Kishioka \& C.A. Carvajal (2005), "IT Substitution for Energy Leads To a Resilient Structure For a Survival Strategy of Japan's Electric Power Industry”, Energy Policy, 33(8), 1069-1084. 
Erkök, B. (2021), "Current Account Deficit and Automotive Sector Nexus

in Turkey: An Input-Output Analysis”, Sosyoekonomi, 29(49), 113-129.

\section{Appendix}

Table: 7

I-O analysis of Turkey

\begin{tabular}{|c|c|c|c|c|c|c|c|c|}
\hline Sector & DBLC & DFLC & TBLC & TFLC & Leakage & Power & Sensitivity & Classification \\
\hline 1 & 0.3271 & 0.6124 & 1.5381 & 2.1793 & 0.0994 & 0.9087 & 1.2875 & FL* Dependent \\
\hline 2 & 0.1398 & 0.1327 & 1.2350 & 1.2067 & 0.0356 & 0.7296 & 0.7129 & Independent \\
\hline 3 & 0.2285 & 0.0316 & 1.4015 & 1.0385 & 0.0761 & 0.8279 & 0.6135 & Independent \\
\hline 4 & 0.1147 & 1.0067 & 1.1912 & 3.9273 & 0.0440 & 0.7037 & 2.3202 & FL Dependent \\
\hline 5 & 0.6575 & 0.5929 & 2.1374 & 1.9575 & 0.1933 & 1.2627 & 1.1564 & Key Sector \\
\hline 6 & 0.5888 & 0.6195 & 2.1359 & 2.0677 & 0.2303 & 1.2619 & 1.2216 & Key Sector \\
\hline 7 & 0.5203 & 0.3443 & 1.8857 & 1.4945 & 0.2039 & 1.1140 & 0.8829 & BL* Dependent \\
\hline 8 & 0.5005 & 0.6834 & 1.8844 & 2.2120 & 0.3178 & 1.1132 & 1.3068 & Key Sector \\
\hline 9 & 0.6013 & 0.4757 & 2.0915 & 1.7000 & 0.3188 & 1.2356 & 1.0043 & Key Sector \\
\hline 10 & 0.4380 & 1.0436 & 1.5422 & 2.7754 & 0.3933 & 0.9111 & 1.6396 & FL Dependent \\
\hline 11 & 0.3150 & 1.2259 & 1.4958 & 3.4050 & 0.2118 & 0.8837 & 2.0116 & FL Dependent \\
\hline 12 & 0.3056 & 0.1729 & 1.4971 & 1.2087 & 0.1622 & 0.8845 & 0.7140 & Independent \\
\hline 13 & 0.5892 & 0.4716 & 1.9977 & 1.8096 & 0.3776 & 1.1802 & 1.0690 & Key Sector \\
\hline 14 & 0.5746 & 0.3818 & 1.9725 & 1.6729 & 0.1955 & 1.1653 & 0.9883 & BL Dependent \\
\hline 15 & 0.5300 & 1.1612 & 1.8752 & 2.9787 & 0.3115 & 1.1078 & 1.7597 & Key Sector \\
\hline 16 & 0.5098 & 0.3430 & 1.9368 & 1.5422 & 0.2540 & 1.1442 & 0.9111 & BL Dependent \\
\hline 17 & 0.2047 & 0.2732 & 1.3245 & 1.3825 & 0.1235 & 0.7825 & 0.8167 & Independent \\
\hline 18 & 0.5236 & 0.3857 & 1.9470 & 1.5776 & 0.2952 & 1.1502 & 0.9320 & BL Dependent \\
\hline 19 & 0.3171 & 0.2361 & 1.5686 & 1.3409 & 0.1774 & 0.9267 & 0.7922 & Independent \\
\hline 20 & 0.4962 & 0.2854 & 1.9062 & 1.4168 & 0.3185 & 1.1261 & 0.8370 & BL Dependent \\
\hline 21 & 0.2345 & 0.0913 & 1.4033 & 1.1154 & 0.1224 & 0.8290 & 0.6590 & Independent \\
\hline 22 & 0.5186 & 0.1920 & 1.9504 & 1.2325 & 0.2195 & 1.1523 & 0.7281 & BL Dependent \\
\hline 23 & 0.4524 & 0.2385 & 1.7919 & 1.3672 & 0.2164 & 1.0586 & 0.8077 & BL Dependent \\
\hline 24 & 0.7816 & 1.2543 & 2.7032 & 4.3601 & 0.4790 & 1.5970 & 2.5758 & Key Sector \\
\hline 25 & 0.3273 & 0.0947 & 1.6985 & 1.1369 & 0.1217 & 1.0035 & 0.6717 & BL Dependent \\
\hline 26 & 0.2701 & 0.3412 & 1.4365 & 1.8367 & 0.1158 & 0.8486 & 1.0851 & FL Dependent \\
\hline 27 & 0.6047 & 0.6457 & 2.1397 & 2.0222 & 0.1917 & 1.2641 & 1.1946 & Key Sector \\
\hline 28 & 0.4177 & 0.2818 & 1.7393 & 1.4676 & 0.1623 & 1.0275 & 0.8670 & BL Dependent \\
\hline 29 & 0.3919 & 1.1061 & 1.6780 & 2.8149 & 0.0944 & 0.9913 & 1.6630 & FL Dependent \\
\hline 30 & 0.3477 & 0.3564 & 1.5915 & 1.5872 & 0.0834 & 0.9402 & 0.9377 & Independent \\
\hline 31 & 0.4478 & 1.2172 & 1.7549 & 3.3346 & 0.1651 & 1.0367 & 1.9700 & Key Sector \\
\hline 32 & 0.4930 & 0.2680 & 1.8101 & 1.4675 & 0.1639 & 1.0694 & 0.8670 & BL Dependent \\
\hline 33 & 0.5832 & 0.1967 & 1.9634 & 1.2513 & 0.2932 & 1.1599 & 0.7393 & BL Dependent \\
\hline 34 & 0.3602 & 0.6667 & 1.5943 & 2.1420 & 0.0921 & 0.9418 & 1.2654 & FL Dependent \\
\hline 35 & 0.4509 & 0.1662 & 1.7460 & 1.2496 & 0.1113 & 1.0315 & 0.7382 & BL Dependent \\
\hline 36 & 0.4594 & 0.5088 & 1.8707 & 1.6762 & 0.1244 & 1.1052 & 0.9902 & BL Dependent \\
\hline 37 & 0.4158 & 0.1650 & 1.7895 & 1.2737 & 0.1357 & 1.0572 & 0.7525 & BL Dependent \\
\hline 38 & 0.4955 & 0.5467 & 1.9516 & 2.0974 & 0.1547 & 1.1530 & 1.2391 & Key Sector \\
\hline 39 & 0.3894 & 0.3601 & 1.6719 & 1.5528 & 0.0637 & 0.9877 & 0.9174 & Independent \\
\hline 40 & 0.1825 & 0.3252 & 1.3055 & 1.4934 & 0.0359 & 0.7712 & 0.8823 & Independent \\
\hline 41 & 0.2884 & 0.6918 & 1.4632 & 2.1922 & 0.0411 & 0.8644 & 1.2951 & FL Dependent \\
\hline 42 & 0.6330 & 0.2736 & 2.0644 & 1.4161 & 0.1601 & 1.2196 & 0.8366 & BL Dependent \\
\hline 43 & 0.2883 & 0.3234 & 1.4760 & 1.4724 & 0.0506 & 0.8720 & 0.8699 & Independent \\
\hline 44 & 0.1791 & 1.0137 & 1.3167 & 2.6025 & 0.0638 & 0.7779 & 1.5375 & FL Dependent \\
\hline 45 & 0.0000 & 0.0000 & 1.0000 & 1.0000 & 0.0000 & 0.5908 & 0.5908 & Independent \\
\hline 46 & 0.2331 & 0.5783 & 1.3908 & 1.9007 & 0.0516 & 0.8217 & 1.1229 & FL Dependent \\
\hline 47 & 0.3798 & 0.2359 & 1.6571 & 1.3484 & 0.0839 & 0.9790 & 0.7966 & Independent \\
\hline 48 & 0.1503 & 0.0000 & 1.2603 & 1.0000 & 0.0485 & 0.7446 & 0.5908 & Independent \\
\hline 49 & 0.6561 & 0.5979 & 2.3431 & 2.0285 & 0.1522 & 1.3843 & 1.1984 & Key Sector \\
\hline 50 & 0.5006 & 0.2147 & 1.8630 & 1.2932 & 0.1536 & 1.1006 & 0.7640 & BL Dependent \\
\hline 51 & 0.2123 & 0.2650 & 1.3536 & 1.4181 & 0.0674 & 0.7997 & 0.8378 & Independent \\
\hline 52 & 0.1883 & 0.0567 & 1.3187 & 1.0833 & 0.0348 & 0.7790 & 0.6400 & Independent \\
\hline 53 & 0.6133 & 0.1024 & 2.1589 & 1.1248 & 0.1754 & 1.2754 & 0.6645 & BL Dependent \\
\hline 54 & 0.2310 & 0.8189 & 1.3808 & 2.2143 & 0.0704 & 0.8157 & 1.3081 & FL Dependent \\
\hline 55 & 0.3463 & 0.0783 & 1.6067 & 1.1123 & 0.0966 & 0.9492 & 0.6571 & Independent \\
\hline 56 & 0.1542 & 0.0836 & 1.2752 & 1.1156 & 0.0386 & 0.7533 & 0.6591 & Independent \\
\hline 57 & 0.4142 & 0.0720 & 1.6978 & 1.0788 & 0.1173 & 1.0030 & 0.6373 & BL Dependent \\
\hline 58 & 0.3567 & 0.0000 & 1.6288 & 1.0000 & 0.0967 & 0.9622 & 0.5908 & Independent \\
\hline 59 & 0.2761 & 0.1203 & 1.5124 & 1.1625 & 0.0463 & 0.8935 & 0.6868 & Independent \\
\hline 60 & 0.5123 & 0.1075 & 2.0020 & 1.1597 & 0.1254 & 1.1827 & 0.6851 & BL Dependent \\
\hline 61 & 0.3483 & 0.1159 & 1.7125 & 1.1522 & 0.0856 & 1.0117 & 0.6807 & BL Dependent \\
\hline 62 & 0.4233 & 0.0430 & 1.7444 & 1.0638 & 0.1814 & 1.0305 & 0.6285 & BL Dependent \\
\hline 63 & 0.5374 & 0.0157 & 1.9516 & 1.0199 & 0.1800 & 1.1529 & 0.6025 & BL Dependent \\
\hline 64 & 0.0000 & 0.0000 & 1.0000 & 1.0000 & 0.0000 & 0.5908 & 0.5908 & Independent \\
\hline
\end{tabular}

* BL: Backward Linkage, FL: Forward Linkage.

20: Motor vehicles, trailers and semi-trailers.

Sector codes, NACE Rev. 2 sections seq no and Description can be seen: L_2010210EN.01000101.xml (europa.eu) 
Erkök, B. (2021), "Current Account Deficit and Automotive Sector Nexus in Turkey: An Input-Output Analysis", Sosyoekonomi, 29(49), 113-129. 